\title{
Sericin from the Cocoons of Silkworm, Antheraea mylitta (L) and Bombyx mori (L) for the Reduction in Hydrogen Peroxide Induced Oxidative Stress in Feline Fibroblasts
}

\author{
Nikita Rajanikant Jadhav ${ }^{1 *}$, Samiksha Dattatray Giri ${ }^{1}$ and \\ Vitthalrao Bhimasha Khyade ${ }^{2,3,4}$
}

\author{
${ }^{1}$ Shardabai Pawar Mahila Mahavidyalaya, Shardanagar (Baramati) - 413115, India \\ ${ }^{2}$ Malegaon Sheti Farm, Agricultural Development Trust Baramati, Shardanagar, (Malegaon \\ Khurd) Post Box No - 35, Baramati, Pune 413 115, Maharashtra, India \\ ${ }^{3}$ Department of Zoology, Shardabai Pawar Mahila Mahavidyalaya, Shardanagar Tal. \\ Baramati Dist. Pune - 413115, India \\ ${ }^{4}$ Dr. APIS", Shrikrupa Residence, Teachers Society, Malegaon Colony (Baramati) Dist. Pune \\ - 413115, India \\ *Corresponding author
}

\section{Keywords}

Antioxidant activity, Fibroblast cell line, Hydrogen peroxide, Oxidative stress, Moracin

Article Info

Accepted:

06 September 2018

Available Online:

10 October 2018
A B S T R A C T

The silk fiber of cocoons of silkworms of both the families consists of two major proteins, fibroin and sericin. The fibrion forms central core and sericin forms envelop. Fibroin and sericin, of mulberry silkworm, Bombyx mori deserve appreciable physioc-chemical properties and therefore, they are now recognized as excellent biomaterials in the field of tissue engineering, biotechnology and therapy. Sericin contributes about 20-30 per cent of total cocoon weight. It is characterized by its high content of serine and 18 amino acids, including essential amino acids. There are different methods of isolation of sericin from silk thread. Solubility, molecular weight, and gelling properties of sericin depend on the method of isolation. It has wide applications in pharmaceuticals and cosmetics such as, wound healing, bioadhesive moisturizing, antiwrinkle and antiaging. The present attempt is concerned with assessment of potential regarding antioxidant activity of Sericin from silk from cocoons of non-mulberry silkworm, Antheraea mylitta and mulberry silkworm, Bombyx mori (L) through the use of hydrogen peroxide induced stress in skin fibroblast cell line culture (AH927). Cells treated with sericin exhibited significant cell viability comparable to that of control group ( $\mathrm{P}>0.05$ ). The fibroblasts pre-incubated with sericin of both the species at $100 \mathrm{ng} / \mathrm{ml}$ had significantly decreased $(\mathrm{P}<0.01)$ catalase activity. The oxidative stress through hydrogen peroxide was found responsible for significant increase $(\mathrm{P}<0.01)$ in the release of enzyme (LDH) in comparison with untreated control. The sericin treatment definitely serving to restore the original membrane integrity of the cells. The aqueous form of silk sericin, from a natural source like silkworm cocoon, serves as ideal antioxidant source and may be used to treat the cancer cells. 


\section{Introduction}

The credit of much impetus to the role of reactive oxygen species (ROS) such as superoxide, hydrogenperoxide, and hydroxyl radicals in the initiation and progression of the aging process goes to the free radical theory of aging (Harman, 1956). Increased levels of reactive oxygen species (ROS) are responsible for damage of various cellular processes. The hydrogen peroxide is responsible for release of hydroxyl radical, which in its turn reacting with different transition metals. The harmful effects of reactive oxygen species (ROS) include damage the DNA, lipid peroxidation, oxidation of proteins and deactivation of enzymes through oxidation of co-factors, leading to mutagenesis and carcinogenesis (Datta et al., 2002). There is voluminous research with reference to discover new antioxidant compounds from plant and animal origin to prevent free radical damage (Rada $e t$ al., 2008; Conner et al., 2002; Brooker, 2011; Arora et al., 2003; Hashim et al., 2005; Verhoeyen et al., 2002; Yang et al., 2006). Polypeptide with antioxidant property has also been reported in marine bivalve (Farrer's scallop, also known as the Chinese scallop), Chlamys farreri (Ghosh et al., 2006 and Han et al., 2004). The lepidopteran insects of family Bombycidae and Saturniidae are well known to produce commercially important silks. Domesticated mulberry silkworm, Bombyx mori represents family Bombycidae and wild non-mulberry silkworms, Antheraea mylitta represents family Saturniidae. The silk fiber of cocoons of silkworms of both the families consists of two major proteins, fibroin and sericin. The fibrion forms central core and sericin forms envelop. Fibroin and sericin, of mulberry silkworm, Bombyx mori deserve appreciable physioc-chemical properties and therefore, they are now recognized as excellent biomaterials in the field of tissue engineering, biotechnology and therapy. The fibroin is the water-insoluble protein and sericin is water soluble. The fibroin of silk fibre of mulberry silkworm, has been recognized as a substrate for growth and adherence of cells in culture (Altman et al., 2003; Jin et al., 2004; Meinel et al., 2005; Vepari and Kaplan, 2007; Wang et al., 2006) and sericin is used as abiomaterial. This utilization is due to its antibacterial and UV resistant properties of sericin (Zhang, 2002). It would be beneficial for economy and environment if this sericin can be fully utilized as a green material. There are some reports on lipid peroxidation through sericin (Kato et al., 1998), antitumor properties sericin (Zhaorigetu et al., 2003) and with no immunogenicity (Kato et al., 1998).

All the biomaterial related applications of silk proteins involve in vitro studies on cells prior to their implantation in vivo. Sericin is a group of polypeptides comprised of 17-18 types of amino acids (Ogino et al., 2006, 2002); among which serine, aspartic acid, and glycine are the three most abundant amino acid (Ogino, M. et al., 2006; Kundu et al., 2008). Sericin was previously reported to elicit an immune response, which was later demonstrated to be triggered when sericin remains physically associated with fibroin (Panilaitis et al., 2003; Ogino, M. et al., 2002; Ogino, M. et al., 2006; Kundu et al., 2008; Aramwit et al., 2002). Sericin on its own is found to have no immunogenicity and is now utilized in biomedical applications (Zhang et al., 2006; Zhang et al., 2006). An increasing number of studies have focused on the usefulness of sericin in biomedical applications. Sericin was reported to have diverse biological activities, such as anti-oxidation, anti-bacterium, anticoagulation and promoting cell growth and differentiation (Baba et al., 1996; Kato et al., 1998, Sasaki et al., 2000; Takeuchi et al., 2005; Miyazaki et al., 2004). In the field of regenerative medicine, owing to its biodegradability, easy availability, and hydrophilicity with many polar side groups, 
sericin is mostly copolymerized, cross linked, or blended with other polymers to form various scaffolds in order to help obtain improved properties for relevant biomedical applications (Vepari et al., 2007; Wang et al., 2006; Zhang et al., 2002; Kato et al., 1998; Zhaorigetu et al., 2003; Zhang et al., 2006; Chen and Ames,1994); such as skin regeneration (69). Besides being jointly fabricated with other biomaterials, the possibility of using only pure sericin to generate scaffolds has just begun to be explored. Pure sericin 2D films (Nayak et al., 2012; Lim et al., 2012; Teramoto et al., 2008; Turbiani et al., 2011), fragile gels (76) and 3D sponge-like matrices were reported (Nishida, A. et al., 2011; Nayak et al., 2013). However, sericin used in these studies is extracted through the conventional harsh method involving high heat and alkali, which are known to cause the degradation of sericin, producing polypeptides with low molecular weights that are physically fragile and highly soluble, posing a challenge for effective cross linking. It remains unclear whether the scaffolds generated using sericin with an intact protein profile will possess any unrevealed physical and chemical properties, which might be potentially valuable for tissue engineering applications. The present attempt was planned to analyse the antioxidant influence of sericin of silk of the cocoons of the mulberry silkworm, Bombyx mori and non-mulberry, tropical tasar silkworm Antheraea mylitta, in skin fibroblast cell line, exposed to hydrogen peroxide for 24 Hours.

\section{Materials and Methods}

The experimentation was carried out through the steps like: cell culture of skin derived fibroblast; separation and isolation of sericin from cocoons; analysis of cell viability; the phase contrast and fluorescence microscopy; influence of pre-treatment with silk protein sericin for $24 \mathrm{hrs;}$ cell homogenate preparation; analysis of lactate dehydrogenase (LDH); catalase analysis; lipid peroxidation analysis through thiobarbituric acid reactive substances (TBARS) and malondialdehyde (MDA) and statistical analysis of the data.

\section{Cell culture of skin derived fibroblast}

The skin fibroblast (feline) cell line (AH927) was procured from National Centre for Cell Science, Pune, India. This skin fibroblast (feline) cell line was used for further processing. Dulbecco's modified Eagle's medium (DMEM) supplemented with 10\% fetal bovine serum and streptomycin-penicillin $(10 \mu \mathrm{g} / \mathrm{ml})$ were used as culture medium. The cells were incubated at 37 degree Celsius. The percentage of carbon dioxide in the cabinet of culture was five percent. Cells were sub cultured at intervals of 3 days and those between passages 4-8 were used for further experimentations (Zhaorigetu, 2003).

\section{Separation and isolation of sericin from cocoons}

The sericin was separated and isolated from the cocoons of non-mulberry silkworm, Antheraea mylitta and mulberry silkworm Bombyx mori through the use of standard protocol described by Sofia et al., (2001). The cocoons of both species (Antheraea mylitta and Bombyx mori) were cut into smaller pieces. The cocoon pieces were boiled in the solution of $0.02 \mathrm{M} \mathrm{Na}_{2} \mathrm{CO}_{3}$. This boiling was carried out for half an hour. The supernatant of resulted solution was decanted out and was dialyzed to obtain sericin. The protein solution was dialyzed against several changes of Milli Q water (ultrapure water of Type 1). The crude extracts of sericin (along with all fractions) were used for further experimentations. Further, $8 \%$ SDSPAGE was carried out to confirm the presence of proteins. 


\section{Analysis of cell viability}

For the purpose to analyse the cell viability, the extent of reduction of the methyl thiazolyl tetrazolium compound (MTT) was utilized (Mossman, 1983). The cells of culture AH927were seeded in 96-well plates $(1 \times 104$ cells/well) in DMEM medium containing 10\% fetal bovine serum. After the overnight culture, they were treated with different concentrations $(0,0.1,0.2,0.5$ and $1.0 \mathrm{mM})$ of hydrogen peroxide $\left(\mathrm{H}_{2} \mathrm{O}_{2}\right)$ for $24 \mathrm{hrs}$. This hydrogen peroxide $(\mathrm{H} 2 \mathrm{O} 2)$ was freshly prepared from $30 \%$ stock solution (Sigma).The untreated cells were served as control. At the end of incubation, the media in wells were removed and replaced with $200 \mu \mathrm{l}$ of fresh media containing $20 \mu \mathrm{l}$ MTT solution $(5 \mathrm{mg} / \mathrm{ml})$ and incubated at 37 degree Celsius for $4 \mathrm{hrs}$. Then, the media-containing MTT were removed. Addition of $200 \mu \mathrm{l}$ of DMSO was made. This was for the purpose to dissolve the formazan crystals formed in the viable cells. The optical density was recorded in Biorad 550 microplate reader at $595 \mathrm{~nm}$. The result, extent of $\mathrm{H}_{2} \mathrm{O}_{2}$ mediated cell death was expressed as the percentage of cell viability in control cells (Tesco et al., 1992; Ahmad and Pardini, 2000; Ennamany et al., 1995; Sasaki et al., 2000). Each experiment was repeated for four times for consistency in the results. The collected data was subjected for statistical analysis.

\section{The phase contrast and fluorescence microscopy}

For the purpose of microscopic observations, 106 cells were seeded on square coverslip $(22 \times 22 \mathrm{~mm})$. This coverslip was placed inside a petri plate and allowed to grow. The entire overnight was utilized for the growth of cells. Thereafter, the cells were treated with $0.5 \mathrm{mM}$ $\mathrm{H}_{2} \mathrm{O}_{2}$ for $24 \mathrm{hrs}$. The growth of the cells was observed under phase contrast and then, cells were washed with the ice-cold sterile phosphate buffered saline (PBS). The cells were then fixed in fixative consisting of methanol: acetone (1: 1). The fixation was carried out for an hour. The cells were rinsed in PBS and incubated with Tween-20 (0.05 $\%)$. For the membrane permeabilization, incubation was carried out for 30 minutes. This was followed by RNase $(10 \mathrm{mg} / \mathrm{ml})$ treatment for half an hour. After rinsing in PBS, cells were exposed to propidium iodide $(1 \mathrm{mg} / \mathrm{ml})$ for half an hour. The cell nuclei were visualized under fluorescence microscope Leica DMR-HC (with camera MP-60). The emission wavelength was consisting of $615 \mathrm{~nm}$ (Takasu et al., 2002 and Dash et al., 2006).

\section{Influence of pre-treatment with silk protein sericin for $24 \mathrm{hrs}$}

As mentioned earlier for assessment of cell viability, the cells were subjected to pretreatment with silk protein sericin individually at different concentrations ranging from 5 to $150 \mathrm{ng} / \mathrm{ml}$ or gelatin (150 $\mathrm{ng} / \mathrm{ml}$ ). Preliminary experiments showed that pretreatment with sericin for 24 hours, before subjecting to oxidative stress due to $0.5 \mathrm{mM}$ $\mathrm{H}_{2} \mathrm{O}_{2}$, gave maximum protection in comparison to 6,12 and 18 hours. The viability was checked by MTT assay after 24 hrs of exposure to hydrogenperoxide (Dash et al., 2007).

\section{Cell homogenate preparation}

The cells $(1 \times 104$ cells/ well $)$ were seeded in petri plates $(35 \mathrm{~mm})$ and allowed to adhere for $24 \mathrm{hrs}$ before treatment with silk protein sericin. The strength of sericin of $100 \mathrm{ng} / \mathrm{ml}$ from both non-mulberry (Antheraea mylitta) and mulberry silkworm (Bombyx mori) was found exhibiting the appreciable protection (from cell viability assays). Therefore, only sericin of $100 \mathrm{ng} / \mathrm{ml}$ from both non-mulberry (Antheraea mylitta) and mulberry silkworm 
(Bombyx mori) were used for further biochemical experimentations. The cells were pre-incubated with 35 and $100 \mathrm{ng} / \mathrm{ml}$ sericin or $150 \mathrm{ng} / \mathrm{ml}$ gelatin (these represent the concentrations where minimum and maximum protective effect was observed for sericin from A. mylitta in cell viability assay) for $24 \mathrm{hrs}$ followed by 24 hours oxidative stress induction (hydrogen peroxide treatment). The cells were washed for two times with ice-cold PBS and they were harvested through the use of $0.025 \%$ Trypsin- $0.02 \%$ EDTA solution. The cells were re-suspended in ice-cold phosphate buffered saline (PBS) and were then homogenized. The cell homogenates were then processed for centrifugation for 5 min at $5,000 \times g$. Supernatant of each sample was used for further biochemical tests (Vitthalrao B. Khyade, 2016).

\section{Analysis of lactate dehydrogenase (LDH)}

Quantitative assessment of fibroblast damage caused by hydrogen peroxide was carried out through the ratio of the enzyme activity released from damaged cells to the activity in undamaged / intact cells, monitored for $24 \mathrm{hrs}$ after induction of the stress. The medium collected after stress induction was centrifuged (for $5 \mathrm{~min}$ at $5,000 \times g$ ) and supernatant used for the assay of enzyme released from damaged cells.

$\%$ release of $\mathrm{LDH}=$ (released into the medium $\div$ Activity in sonicated cells) x 100

Reduction of pyruvate by the enzyme on addition of $\mathrm{NADH}$ was monitored as the change in optical density of the reaction mixture containing $20 \mathrm{mM}$ phosphate buffer (pH 7.4), 3.3mM sodium pyruvate and $2 \mathrm{mM}$ $\mathrm{NADH}$. The LDH activity was expressed as change in absorbance at $340 \mathrm{~nm}$ per minuteas explained by Bergmeyer and Bernt (Vitthalrao B. Khyade, 2016).

\section{Catalase analysis}

The activity of enzyme catalase (CAT) was carried out through the method described by Maehly and Chance (1954). It was assayed by noting the decrease in optical density of $\mathrm{NADH}$ at $240 \mathrm{~nm}$ following the decomposition of hydrogenperoxide (Maehly and Chance, 1954). The reaction mixture consisted of $10 \mathrm{mM}$ phosphate buffer ( $\mathrm{pH} 7.0)$, $30 \mathrm{mM}$ hydrogen peroxide and the enzyme source. The decrease in optical density of the reaction mixture was monitored at $240 \mathrm{~nm}$ for $5 \mathrm{~min}$. The activity of enzyme LDH was expressed as change in optical density per minute. (Extinction coefficient $=0.021)$. The activity of enzyme released into the medium and those in intact cells were determined as described for LDH analysis and expressed in the unit of percentage (Vitthalrao B. Khyade, 2016).

\section{Lipid peroxidation analysis through thiobarbituric acid reactive substances (TBARS) and malondialdehyde (MDA)}

Thiobarbituric acid reactive substances TBARS - are formed as a byproduct of lipid peroxidation (i.e. as degradation products of fats) which can be detected by the TBARS assay using thiobarbituric acid as a reagent. Because reactive oxygen species (ROS) have extremely short half-lives, they are difficult to measure directly. Instead, what can be measured are several products of the damage produced by oxidative stress, such as TBARS (Vitthalrao B. Khyade, 2016). Assay of TBARS measures malondialdehyde (MDA) present in the sample, as well as malondialdehyde generated from lipid hydroperoxides by the hydrolytic conditions of the reaction (Vitthalrao B. Khyade, 2016). MDA is one of several low-molecular-weight end products formed via the decomposition of certain primary and secondary lipid peroxidation products. However, only certain 
lipid peroxidation products generate MDA, and MDA is neither the sole end product of fatty peroxide formation and decomposition, nor a substance generated exclusively through lipid peroxidation. These and other considerations from the extensive literature on MDA, TBA reactivity, and oxidative lipid degradation support the conclusion that MDA determination and the TBA test can offer, at best, a narrow and somewhat empirical window on the complex process of lipid peroxidation.

Use of MDA analysis and/or the TBA test and interpretation of sample MDA content and TBA test response in studies of lipid peroxidation require caution, discretion, and (especially in biological systems) correlative data from other indices of fatty peroxide formation and decomposition (Vitthalrao B. Khyade, 2016).

Another method of determining oxidative stress is to measure the disappearance of antioxidants, such as alpha-tocopherol, from the blood. Because the majority of plasma tocopherols are found in plasma lipids, which have been shown to decrease in the critically ill, any measure of plasma tocopherols in the critically ill population should be indexed to total cholesterol (Vitthalrao B. Khyade, 2016).

Concentration of thiobarbituric acid reactive substances (TBARS) in the medium after induction of oxidative stress was measured according to the protocol by Niehaus and Samuelson (39). $0.5 \mathrm{ml}$ supernatant of each sample was mixed with $0.5 \mathrm{ml}$ thiobarbituric acid reagent (1:1, v: v, mixture of $0.67 \%$ thiobarbituric acid and acetic acid).

The reaction mixture was heated at 95 degree Celsius for an hour. After cooling, centrifugation was carried out at $1,000 \times g$. The optical density of the supernatant was measured at $535 \mathrm{~nm}$.

\section{Data analysis}

For the purpose to get consistency in the results, each experiment was repeated for four times. The collected data was subjected for statistical analysis explained by Norman and Baily (40). The data were presented as mean \pm S.E.M. and compared using one-way ANOVA and Tukeys test. $\mathrm{P}<0.05$ or less was considered to be statistically significant.

\section{Results and Discussion}

The results pertaining the antioxidant potential of silk protein sericin against hydrogen peroxide-induced oxidative stress in skin fibroblasts are presented in Table 1 to 3 (Fig. $1 ; 2(a) ; 2(b)$ and 3) and explained through the parameters, which include: sensitivity of Fibroblast cells to hydrogen peroxide; morphological changes of the cells on exposure to hydrogen peroxide; effect of Sericin treated before the induction of oxidative stress, LDH activity, Catalase activity and lipid peroxidation through the levels of thiobarbituric acid reactive substances (TBARS) and Malondialdehyde (MDA).

\section{Sensitivity of fibroblast cells to hydrogen peroxide}

Viability of fibroblast cells strikingly found decreased in a concentration-dependant manner on treatment with various concentrations of hydrogen peroxide. The LC50 value for $24 \mathrm{hr}$ exposure to hydrogen peroxide was found measured $0.2 \mathrm{mM}$. This result is indicating that, AH927 cells were sensitive to cell damage induced through hydrogen peroxide treatment. The concentration of $0.5 \mathrm{mMhydrogen}$ peroxide was found reducing the cell viability to the percentage $27.383( \pm 4.76)$ and with that of $1.0 \mathrm{mM}$ hydrogen peroxide decreased the viability to the percentage $8.321( \pm 2.49)$ (Fig. 
1). Increase in the concentration of hydrogen peroxide was found significantly affecting on the percent viability of the fibroblast cells. Reduction in percent viability of fibroblast cells treated with hydrogen is responsible for induction of stress.

\section{Morphological changes in fibroblast cells on hydrogen peroxide exposure}

Preliminary MTT assay in the present attempt revealed in that, viability of fibroblast cells was significantly less at $0.5 \mathrm{mM}$ hydrogen peroxide concentrations. The propidium iodide staining was used for the study on morphological changes in cells at concentration of $0.5 \mathrm{mM}$ Hydrogen peroxide.

This method helped further to assess the damage caused by oxidative stress. The observations under phase contrast microscope, the morphology of the fibroblast cells exposed to $0.5 \mathrm{mM}$ Hydrogen peroxide were revealed shrunken and rounded nature of the fibroblast cells. This is in comparison to normal cells. Fluorescence staining of cells revealed that cells exposed to $0.5 \mathrm{mM} \mathrm{H} \mathrm{H}_{2} \mathrm{O}_{2}$ exhibited nuclear condensation.

\section{Effect of sericin treated before the} induction of oxidative stress

The effect of pre-treatment of cells with sericin for $24 \mathrm{hrs}$ is presented in Table 2 . The pretreatment of gelatin with the cells for 24 hrs did not show significant protection against Hydrogen peroxide induced oxidative stress.

The one-way analysis of variance revealed that, there was an overall significant difference in cell viability between controls, $\mathrm{H} 2 \mathrm{O} 2$-treated and sericin treated fibroblasts ( $\mathrm{F}=44.47, \mathrm{P}<0.001)$. Subsequent multiple comparisons by Tukeys test indicated that, cell viability was significantly lower $(\mathrm{P}<0.01)$ in hydrogen peroxide-treated when compared with control and sericin treated fibroblasts. The concentrations of 35,50 and $100 \mathrm{ng} / \mathrm{ml}$ sericin were found significantly $(\mathrm{P}<0.05)$ increasing the cell viability. Cells treated with sericin of A. mylitta, at $150 \mathrm{ng} / \mathrm{ml}$ exhibited cell viability comparable to that of control group ( $\mathrm{P}>0.05)$. This result indicates that, pre-incubation with $150 \mathrm{ng} / \mathrm{ml}$ restore the cell viability to normal. The sericin from $B$. mori was found not responding in the same way to restore cell viability to normal at the same concentration.

\section{LDH activity}

Table 3 depicts the percentage of LDH activity released into the medium in normal fibroblast cells, fibroblast cells treated with $0.5 \mathrm{mM}$ hydrogen peroxide for $24 \mathrm{hrs}$, and fibroblast cells pre-incubated with $35 \mathrm{ng} / \mathrm{ml}$ and $100 \mathrm{ng} / \mathrm{ml}$ of sericin from A. mylitta.

The oxidative stress through hydrogen peroxide was found responsible for significant increase $(\mathrm{P}<0.01)$ in the release of enzyme $(\mathrm{LDH})$ in comparison with untreated control and cells pre-incubated with $100 \mathrm{ng} / \mathrm{ml}$ of sericin before hydrogen peroxide treatment. The oxidative stress through hydrogen peroxide is responsible for the loss of membrane integrity of the cells. The sericin treatment definitely serving to restore the original membrane integrity of the cells.

\section{Catalase activity}

Rate of catalase activity in various treated cellsand control are presented in Table 3 . Catalase activity was significantly high ( $\mathrm{P}$ $<0.01)$ in medium of cells treated with hydrogen peroxide $(80.608 \%)$ compared to control (18.434\%). The fibroblasts preincubated with sericin of both the species of silkworm (Antheraea mylitta and Bombyx mori) at $100 \mathrm{ng} / \mathrm{ml}$ had significantly decreased $(\mathrm{P}<0.01)$ catalase activity. 
Table.1 Cell viability (extent of reduction of the Methyl-thiolyltetrazolium compound (MTT) of feline fibroblast cells (AH927) in presence of Hydrogen Peroxide

\begin{tabular}{|l|}
\hline Concentration of Hydrogen Peroxide (milli mol) \\
\hline 0.00 \\
\hline 0.10 \\
\hline 0.20 \\
\hline 0.50 \\
\hline 1.00
\end{tabular}

\begin{tabular}{|l|}
\hline Percent Viable Cells \\
\hline $100.000( \pm 2.381)$ \\
\hline $073.806( \pm 7.793)$ \\
\hline $051.193( \pm 5.95)$ \\
\hline $027.383( \pm \mathbf{4 . 7 8 6})$ \\
\hline $008.321( \pm 2.492)$ \\
\hline
\end{tabular}

Each value is the mean of three replications.

Figures in parenthesis with $( \pm)$ signs are the standard deviations.

Table.2 Influence of sericin and moracin on the cell viability (extent of reduction of the methylthiazolyl tetrazolium (MTT) of feline fibroblast cells (AH927) treated with Hydrogen Peroxide

\begin{tabular}{|c|c|c|}
\hline S. No. & Group & Percent Viable Cells \\
\hline 1. & Untreated Control & $97.048( \pm 6.134)$ \\
\hline 2. & Hydrogen Peroxide Treated & $28.311( \pm 3.249)$ \\
\hline 3. & Gelatin Treated & $32.502( \pm 2.562)$ \\
\hline 4. & Sericin (A.mylitta) $(150 \mathrm{ng} / \mathrm{ml})$ & $91.287( \pm 2.409)$ \\
\hline 5. & Sericin (B. mori) $(150 \mathrm{ng} / \mathrm{ml})$ & $63.991( \pm 6.117)$ \\
\hline 6. & Moracin (25 ng/ml) & $56.971( \pm 5.516)$ \\
\hline 7. & Moracin (50 ng/ml) & $63.786( \pm 8.463)$ \\
\hline 8. & Moracin (75 ng/ml) & $89.138( \pm 11.645)$ \\
\hline 9. & Moracin (100 ng/ml) & $93.792( \pm 14.861)$ \\
\hline 10. & Moracin (125 ng/ml) & $96.447( \pm 18.687)$ \\
\hline 11. & Moracin (150 ng/ml) & $96.569 \pm 18.889)$ \\
\hline
\end{tabular}

Each value is the mean of three replications.

Figures in parenthesis with $( \pm)$ signs are the standard deviations.

Table.3 Influence of sericin on the activity of Catalase, Lactate Dehdrogenase (LDH) and Malondialdehyde (MDA) homogenate of feline fibroblast cells (AH927) treated with Hydrogen Peroxide

\begin{tabular}{|c|c|c|c|}
\hline Group & Catalase Activity & LDH Activity & MDA Activity \\
\hline Untreated Control & $18.434( \pm 1.426)$ & $35.217( \pm 4.092)$ & $15.652( \pm 1.873)$ \\
\hline $\begin{array}{l}\text { Hydrogen Peroxide } \\
\text { Treated }\end{array}$ & $80.608( \pm 23.912)$ & $69.631( \pm 16.655)$ & $60.263( \pm 21.374)$ \\
\hline Gelatin Treated & $64.956( \pm 18.268)$ & $64.823( \pm 21.319)$ & $61.43 \pm 18.969)$ \\
\hline $\begin{array}{l}\text { Antherea mylitta } \\
\text { Sericin (100 ng/ml) }\end{array}$ & $23.748( \pm 4.832)$ & $63.391( \pm 5.574)$ & $27.387( \pm 3.213)$ \\
\hline $\begin{array}{l}\text { Bombyx mori } \\
\text { Sericin (100 ng/ml) }\end{array}$ & $18.083( \pm 3.715)$ & $57.913( \pm 4.638)$ & $23.478( \pm 4.235)$ \\
\hline
\end{tabular}

Each value is the mean of three replications.

Figures in parenthesis with $( \pm)$ signs are the standard deviations. 
Fig.1 Cell viability (extent of reduction of the methyl thiazolyl tetrazolium compound (MTT) of feline fibroblast cells (AH927) in various concentrations (Milimoles) of hydrogen peroxide

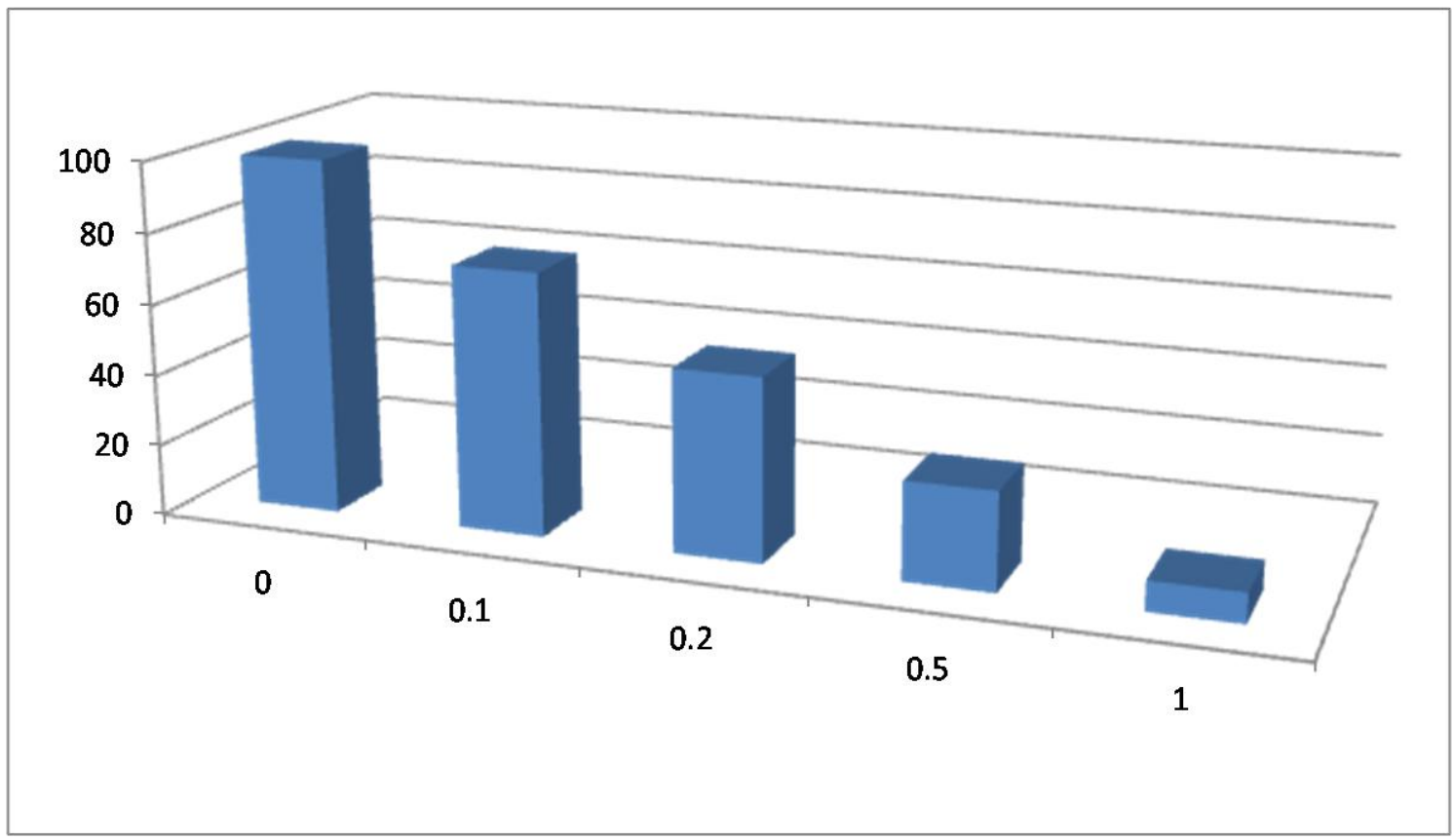

Fig.2 (a) Influence of Sericin (of A. mylitta and B. mori) on the cell viability of feline fibroblast cells (AH927) treated with hydrogen peroxide (Groups: Untreated Control; Hydrogenperoxide treated and gelatin treated group)

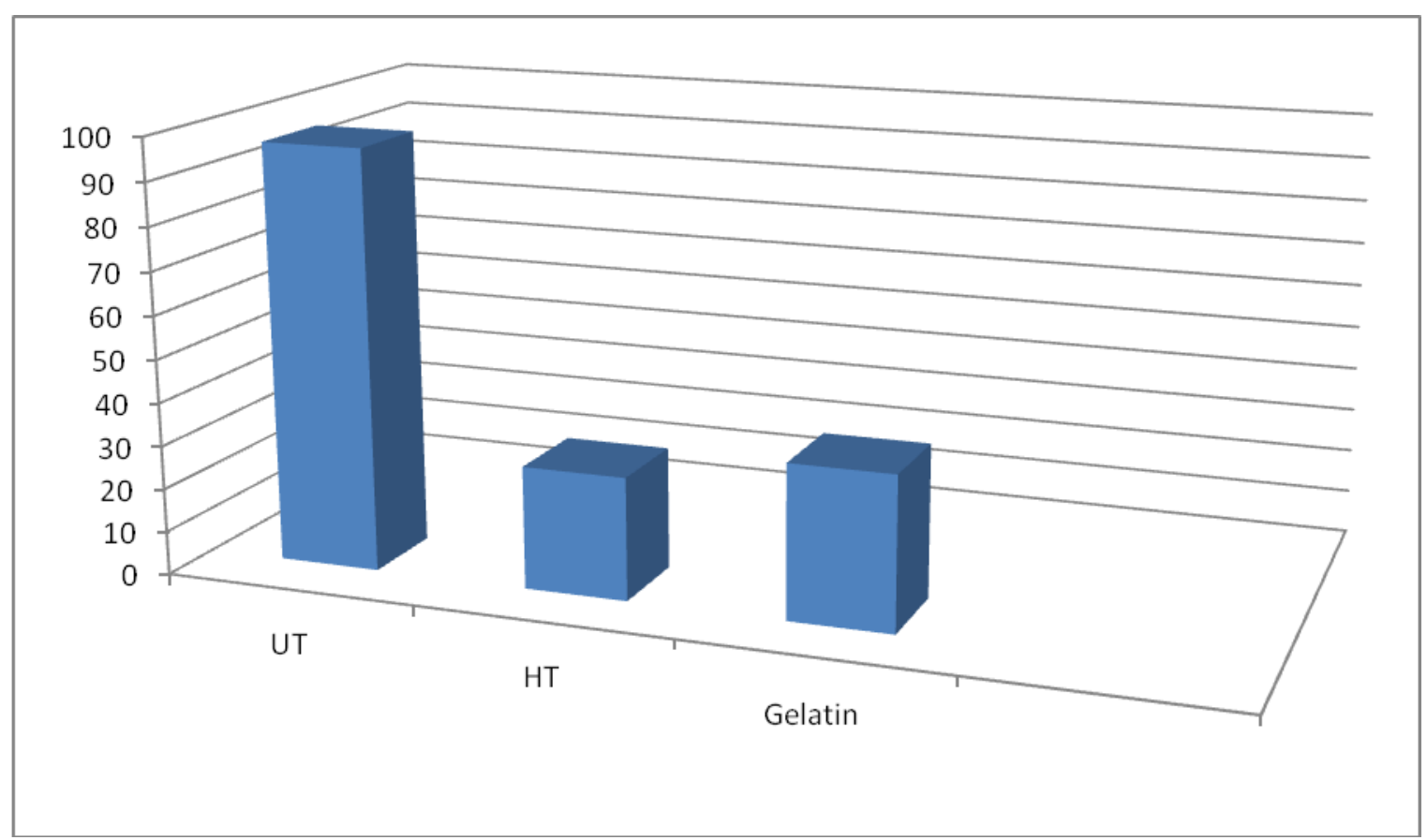

UT: Untreated Control; HT: Hydrogen Peroxide Treated Gelatin: Gelatin Treated 
Fig.2 (b) Influence of sericin (of A. mylitta and B. mori) on the cell viability of feline fibroblast cells (AH927) treated with hydrogen peroxide. (Groups: Sericin Treated)

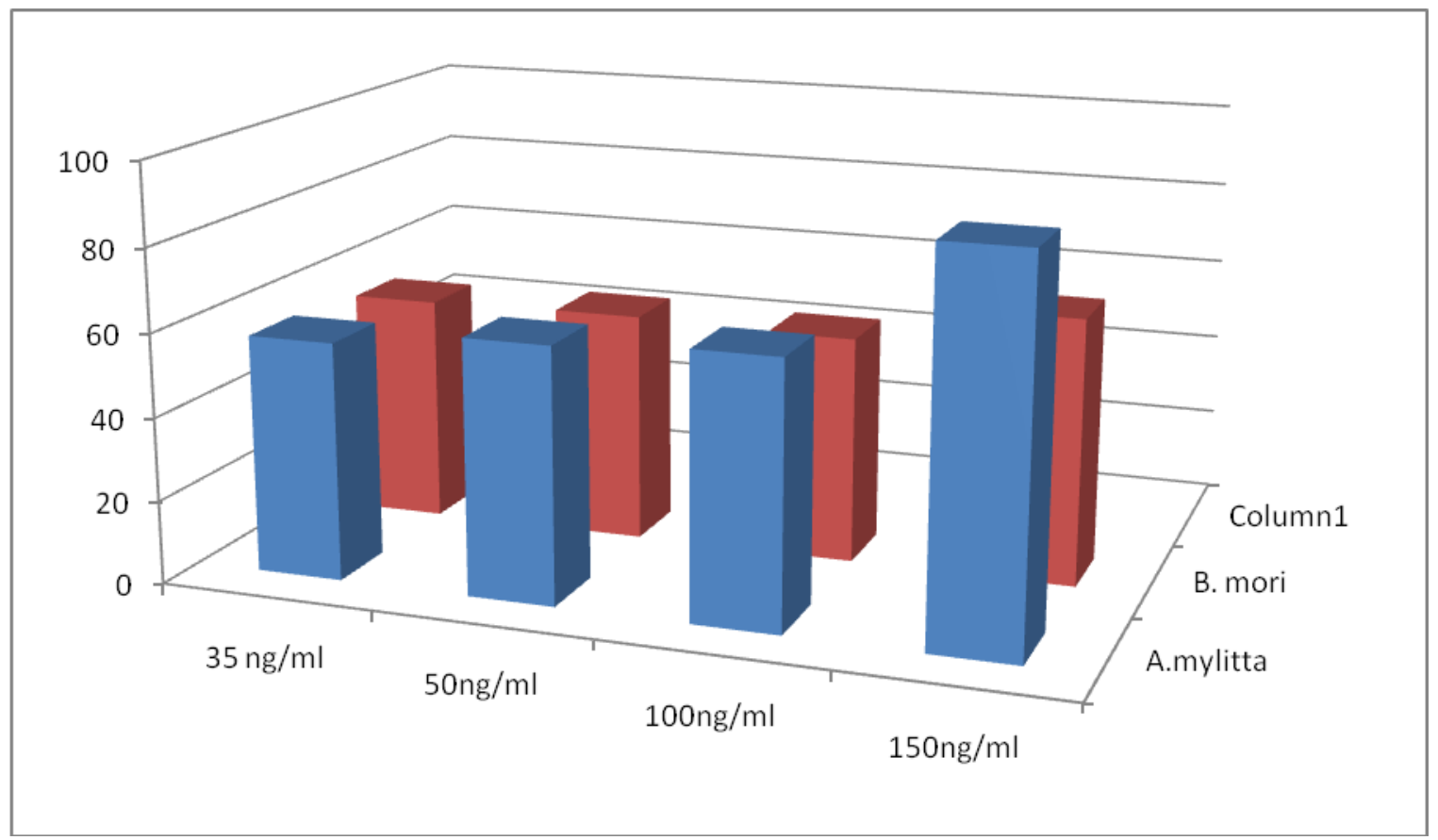

Fig.3 Influence of sericin on the activity of catalase; LDH and MDA in the homogenate of feline fibroblast cells (AH927) treated with hydrogen peroxide
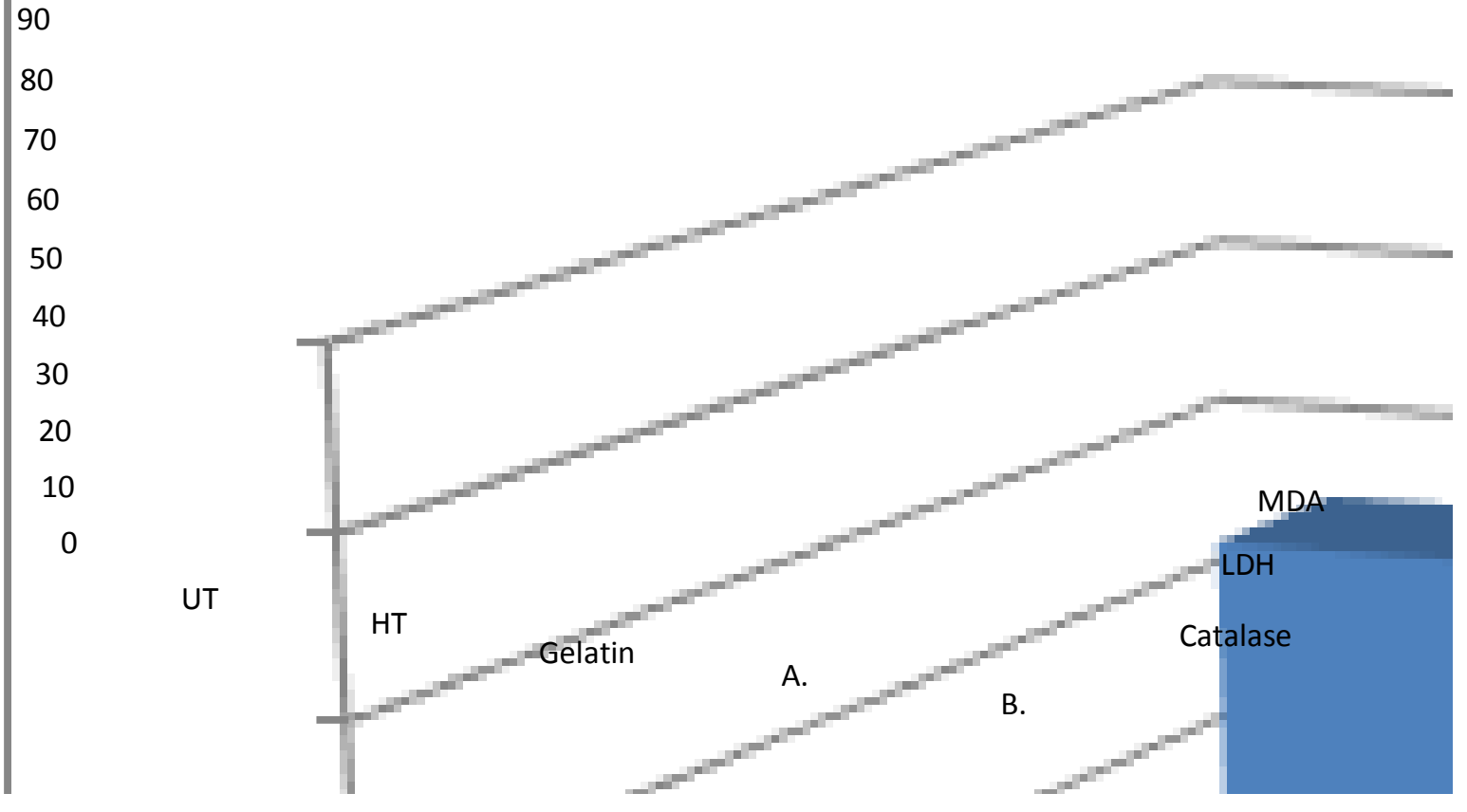


\section{Cell culture of skin derived fibroblast}

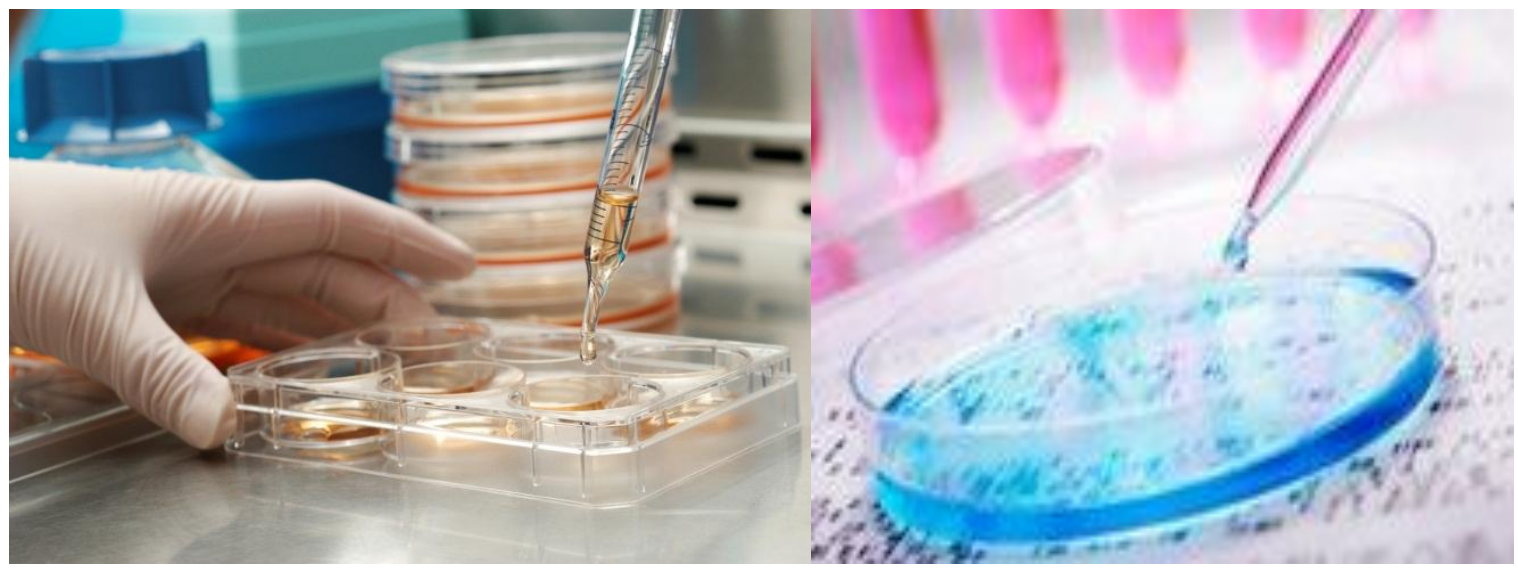

Separation and isolation of sericin from cocoons

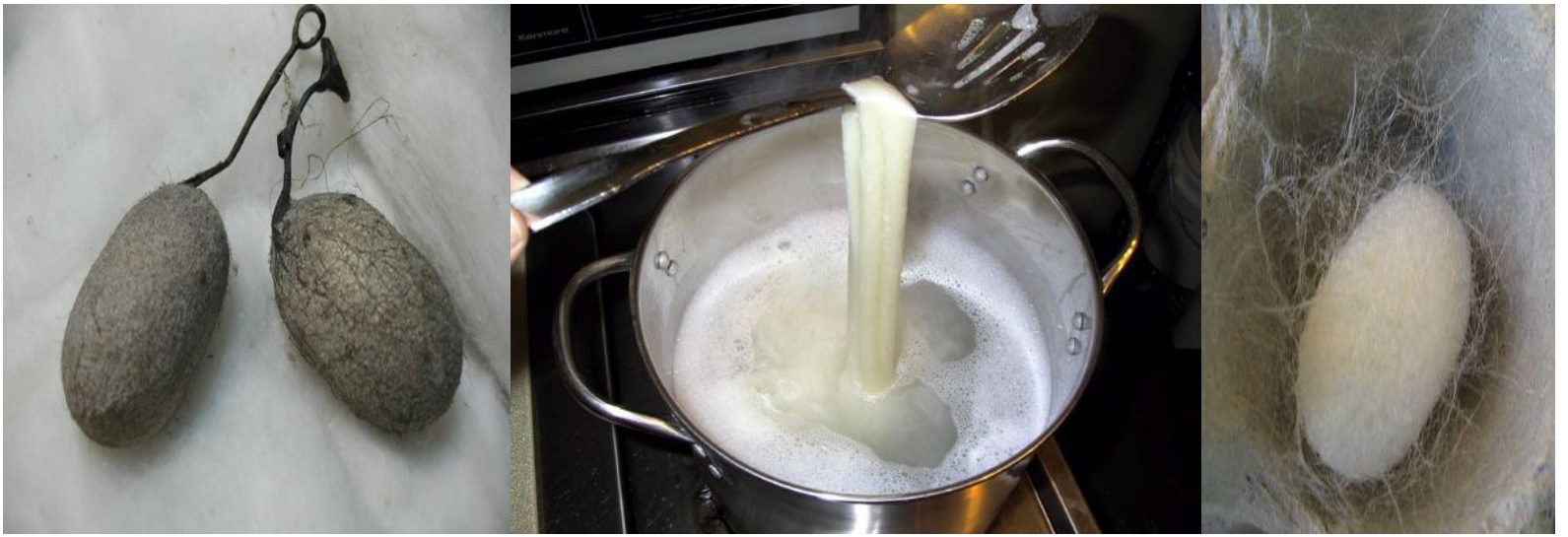

Oxidative stress through treating the cells with hydrogen peroxide is responsible for increase in the catalase activity and sericin treatment have had protective influence on oxidative stress.

Lipid peroxidation through the levels of thiobarbituric acid reactive substances (TBARS) and Malondialdehyde (MDA)

The $\%$ of TBARS/ MDA in the media expressed as $\mathrm{nmol} / \mathrm{ml}$ of the medium is shown in Table 3. The products of peroxidation were significantly high $(\mathrm{P}$ $<0.01)$ in the media of cells treated with hydrogen peroxide. On the other hand the cells pre-incubated with sericin of both the species of silkworm (Antheraea mylitta and
Bombyx mori) at $100 \mathrm{ng} / \mathrm{ml}$ had significantly lower levels of TBARS $(\mathrm{P}<0.05)$.

The hydrogen peroxide is model oxidant because its cellular actions and its fate has been well studied. In the present attempt, the protective effects of silk sericin of both the species of silkworm (Antheraea mylitta and Bombyx mori), on hydrogen peroxide-induced oxidative damage in feline skin fibroblasts were observed. The mechanism of damage by hydrogen peroxide in fibroblast cultures involves the production of reactive oxygen species (ROS) (Vitthalrao B. Khyade et al., 2013). Level of the ROS in cultures preincubated with sericin was significantly decreased as indicated by cell viability tests (MTT assay). Among the silk proteins tested, 
sericin from the non-mulberry silkworm, $A$. mylitta, showed protective effect ata minimum concentration of $35 \mathrm{ng} / \mathrm{ml}$ and restored the viability and normal biochemical profile at $150 \mathrm{ng} / \mathrm{ml}$ which was not observed in case of sericin of $B$. mori. To study further the effect of sericin of A. mylitta on hydrogen peroxide induced oxidative stress, the activities of LDH and catalase were examined. Acceleration of anaerobic metabolic pathway to cope with oxidative stress is reflected from an increase in $\mathrm{LDH}$ activity. The LDH activity of cells subjected to oxidative stress increased significantly in comparison to normal cells. This clearly indicates the loss of membrane integrity through oxidative stress (Ujwala D. Lonkar and Vitthalrao B. Khyade, 2013). The enzyme catalase is involved in the decomposition of hydrogen peroxide to water and oxygen. Therefore, the enzyme catalase is important in protecting cells against oxidative stress (Babita M. Sakdeo and Vitthalrao B. Khyade, 2013). Significant increase in catalase activity in hydrogen peroxide stressed cells when compared to normal cells. A similar trend was also detected in case of the intracellular levels of products of the lipidperoxidation. Malondialdehyde (MDA) is expert to alter the structure and function of the cellular membrane and blocks cellular metabolism leading to cytotoxicity (Vitthalrao B. Khyade et al., 2014). The amounts of $\mathrm{LDH}$, catalase and TBARS were also significantly low in medium of sericin-treated cells when compared to control as well as hydrogen peroxide-treated cells. This attempt indicates that sericin of both the species of silkworm (Antheraea mylitta and Bombyx mori), might be providing protective effect on fibroblast by acting as antioxidant as well as by promoting endogenous antioxidant. Indeed, sericin has previously been reported to possess photo protective effect against the UVB-induced acute damage and colon carcinogenesis (Vitthalrao B. Khyade et al., 2015). The present attempt report the cutaneous cell lines like AH927 fibroblasts are effectively protected against oxidative stress through sericin from the cocoons of the tropical tasar silkworm, A. mylitta. The sericin of both the species of silkworm (Antheraea mylitta and Bombyx mori), contains high amount of polar amino acids. Because of remarkably high content of hydroxyl amino acids (like, serine and threonine), the hydroxy groups of amino acids in sericin might be responsible for the antioxidant action by chelating trace elements (Vepari et al., 2007). For the purpose to observe whether the protective effect of sericin is due to its viscous nature, gelatin (a viscous polymer) was taken as control. Surprisingly enough, it is observed that, viscous compounds like gelatin did not show any protection against oxidative stress through hydrogen peroxide. The protective influence of sericin may be due to its unique antioxidant potential. The skin already possesses extensive and most effective network of the system of antioxidant. Practically, many more of the free radicals produced by various agents can escape this surveillance, inducing substantial damage to cutaneous constituents, especially when skin defense mechanisms are overwhelmed (Vitthalrao B. Khyade and Sadhana D. Deshpande, 2015). The use of antioxidants has been observed to improve cutaneous wound healing significantly (Darr et al., 1992). Consequently, exogenous antioxidants (like sericin) that scavenge reactive oxygen species (ROS) and restore normal redox state are supposed to be beneficial (Dash et al., 2007). Conclusively enough, the present attempt suggests that water-soluble silk sericin, from a natural source like silkworm cocoon, serve as ideal molecule to prevent oxidative stress. Sericin has a long history of being discarded as a waste during the degumming process for separating fibroin from sericin. Each year estimated 50,000 tons of unutilized sericin was discarded in 
degumming wastewater worldwide, posing a contamination threat to environment due to the high oxygen demand for sericin degradation. It would be beneficial for economy and environment if this sericin can be fully utilized as a green material. Use of sericin may also be used in therapy with other conventional non-enzymatic antioxidants. This may open a new avenue for most suitable method for treating the cancer.

\section{Acknowledgement}

4 September is the birthday of Shinya Yamanaka. This research paper is wishing his kind self "Happy Birthday". Expertise Support received From National Centre for Cell Science, Savitribai Phule University of Pune Campus, Ganesh khind, Pune 411007, Maharashtra, India Deserve Appreciations \& Exert Salutary Influence. Help received from International Science Community Association through Hon. Dr. Dipak Sharma served a lot to orchestrate the progression of the present attempt.

\section{References}

Ahmad, S. and Pardini, R. S. (2000) Mechanisms for regulating oxygen toxicity in phytophagous insects. Free Radic. Biol. Med. 8, 401-413.

Ahn, J. S., Choi, H. K., Lee, K. H., Nahm, J. H. and Cho, C. S. Novel mucoadhesive polymer prepared by template polymerization of acrylic acid in the presence of silk sericin. J Appl Polym Sci80, 274-280 (2001).

Altman, G. H., Jakuba, C., Calabro, T., Horan, R. L., Chen, J., Lu, H., Richmond, J. and Kaplan, D. L (2003) Silk-based biomaterials. Biomaterials 24, 401-416.

Aramwit, P., Kanokpanont, S., De-Eknamkul, W. and Srichana, T. (2009). Monitoring of inflammatory mediators induced by silk sericin. J Biosci Bioeng107, 556561.

Arora, S., Kaur, K. and Kaur, S. (2003) Indian medicinal plants as a reservoir of protective phytochemicals. Teratog. Carcinog. Mutagen. 1, 295-300.

Baba, T., Hanada, K. and Hashimoto, I. The study of ultraviolet b-induced apoptosis in cultured mouse keratinocytes and in mouse skin. J Dermatol Sci., 12, 18-23 (1996).

Babita M. Sakdeo and Vitthalrao B. Khyade (2013): Effect of moracin on DMBA TPA induced skin tumor formation in the mice. 2013. International Journal of Advanced Biological Research, Vol. 3 (4): 576 - 583. www.scienceandnature. org/IJABR.../Index\%20IJABR-vol3(4). pdf

Bergmeyer, H. U. and Bernt, E. (1963) Lactate dehydrogenase; In: Methods of Enzymatic Analysis, Bergmeyer, H.U. (ed.), pp 574-579, Academic Press, London, UK.

Brooker, Robert J. (2011). Genetics: analysis and principles (4th ed.). McGraw-Hill Science.

Chen, Q. and Ames, B. N. (1994) Senescence-like growth arrest induced by hydrogen peroxide in human diploid fibroblastF65 cells. Proc. Natl. Acad. Sci. USA 91, 4130-4134.

Cho, K. Y. et al., Preparation of selfassembled silk sericin nanoparticles. Int J Biol Macromol32, 36-42 (2003).

Conner GE, Salathe M, Forteza R; Salathe; Forteza (December 2002). "Lactoperoxidase and Hydrogen Peroxide Metabolism in the Airway". Am J Respir Crit Care Med166 (12): S57-61. doi:10.1164/rccm.2206018. PMID 12471090.

Correlates of Markers of Oxidative Status in the General Population". Am. J. Epidemiol. 2001. doi:10.1093/aje/154.4. 348. 
Darr, D., Combs, S., Dunston, S., Manning, T. and Pinnell, S. (1992) Topical vitamin $\mathrm{C}$ protects porcine skinfrom ultraviolet radiation-induced damage. Br. J. Dermatol.127, 247-253.

Dash, R., Ghosh, S. K., Kaplan, D. L. and Kundu, S. C. (2007) Purification and biochemical characterization of a $70 \mathrm{kD}$ asericin from tropical tasar silkworm, Antheraea mylitta. Comp. Biochem. Physiol. B Biochem. Mol. Biol.147, 129134.

Dash, R., Mukherjee, S. and Kundu, S. C. (2006) Isolation, purification and characterization of silk protein sericin from cocoon peduncles of tropical tasar silkworm, Antheraea mylitta. Int. J. Biol. Macromol. 38, 255-258.

Datta, K., Babbar, P., Srivastava, T., Sinha, S. and Chattopadhyay, P. (2002) p53 dependent apoptosis in gliomacell lines in response to hydrogen peroxide induced oxidative stress. Int. J. Biochem. Cell Biol. 34, 148-157.

Ennamany, R., Marzetto, S., Saboureau, D. and Creppy, E.E. (1995) Lipid peroxidation induced by Boletus satanas: implication in $\mathrm{m} 5 \mathrm{dC}$ variation in Vero cells related to inhibition of cell growth. Cell Biol. Toxicol. 11, 347-354.

Ghosh, A., Sarkar, K., Sil, P. C. (2006) Protective Effect of a $43 \mathrm{kD}$ Protein from the Leaves of the Herb, Cajanus indicus $\mathrm{L}$ on Chloroform Induced Hepatic-disorder. J. Biochem. Mol. Biol. 39, 197-207.

Han, Y. T., Han, Z. W., Yu, G. Y., Wang, Y. J., Cui, R. U.and Wang, C. B. (2004) Inhibitory effect of polypeptide from Chlamys farreri (Marine Bivalve : Farrer's scallop or Chinese scallop)on ultraviolet A-induced oxidativedamage on human skin fibroblasts in vitro. Pharmacol.Res. 49, 265-274.
Harman, D. (1956) Aging: a theory based on free radical and radiation chemistry. $J$. Gerontol. 11, 298-300.

Hashim, M. S., Lincy, V., Remya, V., Teena, M. and Anila, L. (2005) Effect of polyphenolic compounds from Coriandrum sativum on $\mathrm{H} 2 \mathrm{O} 2$-induced oxidative stress in human lymphocytes. Food Chem. 92, 63-65.

http://deepblue.lib.umich.edu/bitstream/handl e/2027.42/24020/0000269.pdf?sequence $=1 \&$ is Allowed $=\mathrm{y}$

Imlay, J. A., Chin, S. M. and Linn, S. (1988) Toxic DNA damage by hydrogen peroxide through the Fenton reaction in vivo and in vitro. Science. 240, 640-642.

Jagetia, G. C., Rajanikant, G. K. and Rao, S. K. (2003) Evaluation of the effect of ascorbic acid treatment in the artificially wounded mouse exposed to different doses of fractionated gamma radiation. Radiat. Res. 159, 371-380.

Janero (1990). "Malondialdehyde and thiobarbituric acid-reactivity as diagnostic indices of lipid peroxidation and peroxidative tissue injury". Free Radic Biol Med 9 (6): 515-40. doi:10.1016/0891-5849(90)90131-2. PMID 2079232.

Jin, H. J., Chen, J., Karageorgiou, V., Altman, G. H. and Kaplan, D. L. (2004) Human bone marrow stromal cell responses on electrospun silk fibroin mats. Biomaterials 25, 1 039-1047.

Katiyar, S. K., Afaq, F., Perez, A. and Mukhtar, H. (2001) Green tea polyphenol (3)-epigallocatechin-3galate treatment of human skin inhibits ultraviolet radiation-induced oxidative stress. Carcinogenesis 22, 287-294.

Kato, N. et al., Silk protein, sericin, inhibits lipid peroxidation and tyrosinase activity. Biosci Biotechnol Biochem62, 145-147 (1998).

Kato, N., Sato, S., Yamanaka, A., Yamada, H., Fuwa, N. and Nomura, M. (1998) 
Silk protein sericin inhibits lipid peroxidation and tyrosinase activity. Biosci.Biotechnol.Biochem.62, 145-147.

Kundu, B. and Kundu, S. C. Silk sericin/polyacrylamide in situ forming hydrogels for dermal reconstruction. Biomaterials33, 7456-7467 (2012).

Kundu, S. C., Dash, B. C., Dash, R. and Kaplan, D. L. Natural protective glue protein, sericin bioengineered by silkworms: Potential for biomedical and biotechnological applications. Prog Polym Sci33, 998-1012 (2008).

Lim, K. S. et al., The influence of silkworm species on cellular interactions with novel pva/silk sericin hydrogels. Macromol Biosci12, 322-332 (2012).

Maehly, A. C. and Chance, B. (1954) The assay of catalase and peroxidase. Methods Biochem.Anal.1, 357-364.

Meinel, L., Hofmann, S., Karageorgiou, V., Kirker-Head, C., McCool, J., Gronowicz, G., Zichner, L., Langer, R., Novakovic, G. V. and Kaplan, D. L. (2005) The inflammatory responses to silk films in vitro and in vivo. Biomaterials, 26, 147-155.

Miyazaki, T. et al., Control of bioresorption of porous alpha-tricalcium phosphate by coating with silk sericin. Trans Mater Res Soc Jpn29, 4 (2004).

Mossman, T. (1983) Rapid colorimetric assay for cellular growth and survival: application to proliferation and cytotoxicity assays. J. Immunol. Methods 65, 55-63.

Nagura, M., Ohnishi, R., Gitoh, Y. and Ohkoshi, Y. Structures and physical properties of cross-linked sericin membranes. J Insect Biotechnol Sericol70, 149-153 (2001).

Nayak, S., Dey, S. and Kundu, S. C. Skin equivalent tissue-engineered construct: Co-cultured fibroblasts/keratinocytes on $3 d$ matrices of sericin hope cocoons. PLoS ONE8, e74779 (2013).
Nayak, S., Talukdar, S. and Kundu, S. C. Potential of $2 d$ crosslinked sericin membranes with improved biostability for skin tissue engineering. Cell Tissue Res347, 783-794 (2012).

Niehaus, W. and Samuelson, B. (1968) Formation of malonaldehyde from phospholipids arachidonate during microsomal lipid peroxidation. Eur. J. Biochem. 6, 126-130.

Nishida, A. et al., Sustained-release of protein from biodegradable sericin film, gel and sponge. Int J Pharm407, 44-52 (2011).

Norman, T. J. and Baily (1955). Statistical Methods. 2nd ed., Halsted Press, John Wiley \& Co., New York, 216 pp.

Ogino, M. et al., Y., Yamada, H. \& Tsubouchi, K. Isolation of three main sericin components from the cocoon of the silkworm, Bombyx mori. Biosci Biotechnol Biochem 66, 2715-2718 (2002).

Ogino, M. et al., Interfacial behavior of fattyacylated sericin prepared by lipasecatalyzed solid-phase synthesis. Biosci Biotechnol Biochem 70, 66-75 (2006).

Oldham; Bowen (1998). "Oxidative stress in critical care: is antioxidant supplementation beneficial?" $(P D F)$. $J$ Am Diet Assoc 98 (9): 1001-8. doi:10.1016/S0002-8223(98)00230-2. PMID 9739800.

Panilaitis, B. et al., Macrophage responses to silk. Biomaterials 24, 3079-3085 (2003).

Pryor, William (1991). "The antioxidant nutrients and disease preventionwhat, do we know and what, do we need to find out?" (PDF). Am J Clin Nulr 53 (1 Suppl): 391S-393S.PMID 1985418.

Pushpa, A., Vishnu, B. V. G. and K.S, T. R. Preparation of nano silk sericin based hydrogels from silk industry waste. J Environ Res Develop8, 243-253 (2013). 
Rada B, Leto TL; Leto (2008). "Oxidative innate immune defenses by Nox/ Duox family NADPH oxidases" (PDF). Contrib Microbiol. Contributions to Microbiology 15: 164-87. doi:10.1159/000136357. ISBN 978-38055-8548-4. PMC 2776633. PMID 18511861.- Review

Sasaki, M., Kato, N., Watanabe, H. \& Yamada, H. Silk protein, sericin, suppresses colon carcinogenesis induced by 1, 2-dimethylhydrazine in mice. Oncol Rep7, 1049-1052 (2000).

Sasaki, M., Kato, N., Watanabe, H. and Yamada, H. (2000) Silk protein, sericin, suppresses colon carcinogenesis induced by 1, 2-dimethylhydrazine in mice.Oncol. Rep. 7, 1049-1052.

Sofia, S., McCarthy, M. B., Gronowicz, G. and Kaplan, D.L. (2001) Functionalized silk-based biomaterials for bone formation. J. Biomed. Mater. Res. 54, 139-148.

Takasu, Y., Yamada, H. and Tsubouchi, K. (2002) Isolationof three main sericin components from the cocoon ofthe silkworm, Bombyx mori. Biosci.Biotechnol.Biochem.66, 27152718.

Takeuchi, A. et al., Heterogeneous nucleation of hydroxyapatite on protein: Structural effect of silk sericin. $J R$ Soc Interface2, 373-378 (2005).

Terada, S., Nishimura, T., Sasaki, M., Yamada, H. and Miki, M. Sericin, a protein derived from silkworms, accelerates the proliferation of several mammalian cell lines including a hybridoma. Cytotechnology, 40, 3-12 (2002).

Teramoto, H., Kameda, T. and Tamada, Y. Preparation of gel gilm from bombyx mori silk sericin and its characterization as a wound dressing. Biosci Biotechnol Biochem., 72, 31893196 (2008).
Tesco, G., Latorraca, P., Piersanti, S., Sorbi, S., Piacentini, S. and Amaducci, L. (1992) Free radical injury in skin cultured fibroblasts from Alzheimer's disease patients. Ann. N. Y. Acad. Sci. 673, 149-153.

Turbiani, F. R. B., Tomadon, J. J., Seixas, F. L. and Gimenes, M. L. Properties and structure of sericin films: Effect of the crosslinking degree. Chem Eng Trans24, 1489-1494 (2011).

Ujwala D. Lonkar and Vitthalrao B. Khyade (2013): Effect of Moracin on DMBA TPA induced cancer in mice, Mus musculus (L). 2013. Annals of Plant Science Vol. 2 No. 10 (2013):412 419. http://ebioscholar.com/ojs/index. php/ap/article/view/628/528

Vaxman, F., Olender, S., Lambert, A., Nisand, G., Aprahamian, M., Bruch, J. F. (1995) Effect of pantothenicacid and ascorbic acid supplementation on human skin wound healing process. A double-blind, prospective and randomized trial. Eur. Surg. Res. 27, 158-166.

Vepari, C. and Kaplan, D. L. (2007) Silk as a biomaterial. Prog. Polym. Sci. 32, 991997.

Verhoeyen, M. E., Bovy, A., Collins, G., Muir, S., Robinson, S., de Vos, C. H. and Colliver, S. (2002) Increasing antioxidant levels in tomatoes through modificationof the flavonoid biosynthetic pathway. J. Exp. Bot.53, 2099-2106.

Vitthalrao B. Khyade and Sharad G. Jagtap (2016). Antioxidant activity and phenolic compounds of mulberry, Morus alba (L) (Variety: Baramatiwali) International Conference on "Plant Research and Resource Management" And 25 ${ }^{\text {th }}$ APSI Silver Jubilee Meet 2016 at T. C. College Baramati 11, 12 and 13 February, 2016. Pages: $374-377$. 
Vitthalrao B. Khyade (2016). Antioxidant activity and phenolic compounds of mulberry, Morus alba (L) (Variety: Baramatiwali). Journal of Medicinal Plant Studies (JMPS) ISSN 2320-3862; 4(2): 04- 07. http://www.plantsjournal.com/arch ives/2016/vol4issue 1/PartA/3-612.pdf

Vitthalrao B. Khyade (2016). Efficiency of Silk sericin from the cocoons of silkworm, Antheraea mylitta (L) and Bombyx mori (L) for treating the Hydrogen Peroxide induced oxidative stress in feline fibroblasts. World Scientific News 44 (2016) 35-49.

Vitthalrao B. Khyade (2016). Efficiency of Silk sericin from the cocoons of silkworm, Antheraea mylitta (L) and Bombyx mori (L) for treating the Hydrogen Peroxide induced oxidative stress in feline fibroblasts. World Scientific News 44 (2016) 35-49.

Vitthalrao B. Khyade and Aziz Sancer (2016). Treating the 7,12-dimethylbenz (a) anthracene (DMBA) induced buccal pouch carcinoma in Syrian hamster, Mesocricetus auratus (L) with ethanolic extractives of leaves of mulberry, Morus alba (L).World Scientific news 30 (2016): 1-13. www.worldscientific news.com

Vitthalrao B. Khyade and Sadhana D. Deshpande (2015). Chemopreventive Efficacy Of Ethanolic Extractives Of Leaves Of Mulberry, Morus alba (L) On 7, 12-DimethylbenzAnthracene (DMBA) Induced Buccal Pouch Carcinoma In Syrian Hamster, Mesocricetus auratus (L). International Journal of Recent Scientific Research,Vol. 6, Issue, 3, pp.31563161, March, 2015. www.recent scientific.com

Vitthalrao B. Khyade; Suryakant M. Mundhe and Shakir Ali Syed (2015). Influence of Ethanolic Extractives of Leaves of Mulberry, Morus alba (L) On 7, 12Dimethylbenz (A) Anthracene (DMBA) Induced Buccal Pouch Carcinoma in Syrian Hamster, Mesocricetus auratus (L). IOSR Journal of Pharmacy and Biological Sciences (IOSR-JPBS) eISSN: 2278-3008, p-ISSN: 2319-7676. Volume 10, Issue 1 Ver. IV (Jan -Feb. 2015), PP 69-75www.iosrjournals.org

Vitthalrao B. Khyade; Vivekanand V. Khyade and Sunanda V. Khyade(2013): Use of Moracin in preventing the cancer. Journal Of Environmental Science, Toxicology And Food Technology (IOSR-JESTFT) e-ISSN: 2319-2402, pISSN: 2319-2399. Volume 4, Issue 5 (May. - Jun. 2013), PP 96104www.Iosrjournals.Org

Vitthalrao B. Khyade; Vivekanand V. Khyade; Sunanda V. Khyade and MayBritt Moser (2014). Influence of Moracin on DMBA-TPA induced skin tumerigenesis in the mouse. International Journal of Bioassays 3 (11): 3510 - 3516. ISSN: 2278-778X. www.ijbio.com

Wang, Y., Kim, H. J., Vunjak-Novakovic, G. and Kaplan, D. L. (2006) Stem cellbased tissue engineering with silk biomaterials. Biomaterials 27, 60646082.

Yang, Y., Wang, J., Xu, C., Pan, H. and Zhang, Z. (2006) Maltol inhibits apoptosis of human neuroblastoma cells induced by hydrogen peroxide. $J$. Biochem. Mol. Biol. 39,145-149.

Zhang, Y. Q. (2002) Applications of natural silk protein sericin in biomaterials. Biotechnol. Adv. 20, 91-100.

Zhang, Y. Q. et al., Silk sericin-insulin bioconjugates: Synthesis, characterization and biological activity. J Control Release 115, 307-315 (2006).

Zhang, Y. Q., Tao, M. L., Shen, W. D., Mao, J. P. and Chen, Y. H. (2006) Synthesis 
of silk sericin peptides-L-asparaginase (SS-ASNase) bioconjugates and their characterization. J. Chem. Technol. Biotechnol. 81, 136-145.

Zhang, Y.-Q., Tao, M.-L., Shen, W.-D., Mao, J.-P. and Chen, Y.-h. Synthesis of silk sericin peptides-l-asparaginase bioconjugates and their characterization. J Chem Technol Biotechnol81, 136-145 (2006).

Zhaorigetu, S., Yanaka, N., Sasaki, M., Watanabe, H. and Kato, N. (2003) Inhibitory effects of silk protein, sericin on UVB-induced acute damage and tumor promotion by reducing oxidative stress in the skin of hairless mouse. $J$. Photochem. Photobiol. B, Biol. 71, 1117.

Zuliani, T., Denis, V., Noblesse, E., Schnebert, S., Andre, P., Dumas, M. and Ratinaud, M. H. (2005) Hydrogen peroxide-induced cell death in normal human keratinocytesis differentiation dependent. Free Radic. Biol. Med. 38,307-316.

\section{How to cite this article:}

Nikita Rajanikant Jadhav, Samiksha Dattatray Giri and Vitthalrao Bhimasha Khyade. 2018. Sericin from the Cocoons of Silkworm, Antheraea mylitta (L) and Bombyx mori (L) for the Reduction in Hydrogen Peroxide Induced Oxidative Stress in Feline Fibroblasts. Int.J.Curr.Microbiol.App.Sci. 7(10): 641-658. doi: https://doi.org/10.20546/ijcmas.2018.710.072 